\title{
Validasi Algoritma Estimasi Konsentrasi Chl-A pada Citra Satelit Landsat 8 dengan Data In-Situ (Studi Kasus: Perairan Selatan Pulau Lombok, NTB)
}

\author{
Umroh Dian Sulistyah $^{1}$, Lalu Muhamad Jaelani ${ }^{1}$, Gathot Winarso ${ }^{2}$ \\ ${ }^{1}$ Jurusan Teknik Geomatika, Fakultas Teknik Sipil dan Perencanaan, Institut Teknologi Sepuluh Nopember (ITS) \\ Kampus ITS Sukolilo, Surabaya 60111 Indonesia \\ ${ }^{2}$ Lembaga Penerbangan dan Antariksa Nasional \\ e-mail:1mjaelani@geodesy.its.ac.id,gathot_winarso@hotmail.com
}

\begin{abstract}
Abstrak-Chl-a merupakan salah satu parameter indikator tingkat kesuburan suatu perairan. Perairan laut selatan Pulau Lombok merupakan perairan yang berada di Wilayah Pengelolaan Perikanan Republik Indonesia pada zona 573 dengan menghasilkan perikanan tangkap yang tinggi. Dengan memanfaatkan teknologi penginderaan jauh Landsat 8 membuat pemetaan distribusi Chl-a lebih efisien dan akurat untuk mengekstrak parameter fisik perairan laut selatan Pulau Lombok. Akurasi parameter fisik yang diturunkan dari data penginderaan jauh tergantung pada algoritma koreksi atmosfer serta algoritma model untuk menghitung konsentrasi Chl-a.

Pada penelitian ini, dengan menggunakan Landsat 8 pada bulan September 2014 akan dilakukan validasi algoritma estimasi konsentrasi Chl-a Jaelani terhadap data in-situ di perairan laut selatan Pulau Lombok dengan menggunakan metode koreksi atmosfer 6SV dan Flaash serta digunakan produk reflektanpermukaan (surface-reflectance) USGS yang sudah terkoreksi atmosfer. Hasil validasi konsentrasi $\mathrm{Chl}$-a dengan algoritma Jaelani memiliki $N M A E$ terbaik dari citra Landsat 8 dengan koreksi atmosfer metode $6 \mathrm{SV}$ yaitu sebesar $26,095 \%$.

Dalam penelitian ini dibuat algoritma model estimasi konsentrasi Chl-a yang sesuai dengan karakteristik perairan laut selatan Pulau Lombok dengan korelasi tertinggi $\left(R^{2}=0,551\right)$ menggunakan perbandingan $\log \left(\operatorname{Rrs}\left(\lambda_{4}\right)\right)$ dan $\log \left(\operatorname{Rrs}\left(\lambda_{5}\right)\right)$. Hasil validasi konsentrasi Chl-a dengan algoritma model $\mathrm{Chl}$-a baru memiliki $N M A E$ terbaik dari citra Landsat 8 dengan koreksi atmosfer metode 6SV yaitu sebesar 13,484\%. Hal ini menunjukkan bahwa algoritma model Chl-a baru untuk perairan laut selatan Pulau Lombok lebih baik dalam mengekstrak data kualitas air dari data penginderaan jauh pada lokasi penelitian dibandingkan dengan algoritma Chl-a Jaelani.
\end{abstract}

Kata Kunci - Chl-a, Landsat 8, NMAE, Surface reflectance, Validasi.

\section{PENDAHULUAN}

$\mathrm{P}$ ERAIRAN Lombok merupakan salah satu perairan Indonesia yang berada di Wilayah Pengelolaan Perikanan Republik Indonesia (WPP-RI) 573. Pada perairan bagian selatan Pulau Lombok memiliki potensi perikanan tangkap yang cukup tinggi menghasilkan 11.603,8 ton pada tahun 2013 [1]. Potensi perikanan tangkap yang tinggi ini tidak terlepas dari kenyataan bahwa perairan Lombok memiliki produktivitas perairan yang tinggi [2].

Produktivitas perairan yang tinggi menandakan kesuburan suatu perairan dengan melihat jumlah produktivitas primer yang dihasilkan pada perairan tersebut untuk menghasilkan fitoplankton [3]. Kelimpahan fitoplankton yang tinggi diduga akan meningkatkan populasi ikan, dimana ketersediaan makanannya melimpah di perairan tersebut [4]. Bagian terpenting dari pigmen fotosintesis yang dikandung oleh semua dari jenis fitoplankton yang masih hidup di laut adalah klorofila (Chl-a) [5]. Mengingat pigmen tersebut merupakan pigmen utama dari fitoplankton, sehingga konsentrasi fitoplankton dapat diidentifikasi.

Perkembangan teknologi khususnya dalam penginderaan jauh, menyebabkan pelaksanaan pemetaan distribusi Chl-a menjadi lebih efisien dengan banyaknya aplikasi penginderaan jauh yang digunakan untuk pemantauan aktifitas lingkungan perairan. Metode penginderaan jauh ini memanfaatkan satelit Landsat 8 dalam mengidentifikasi kualitas perairan selatan Pulau Lombok. Dalam penelitian ini, digunakan data citra satelit Landsat 8 Level 1T tahun 2014 dan data Surface Reflectance (reflektan-permukaan) satelit Landsat 8 produk dari USGS tahun 2014 untuk memetakan kondisi perairan.

Dalam penelitian ini mengkaji mengenai distribusi konsentrasi Chl-a di perairan selatan Pulau Lombok, NTB. Perhitungan mengenai Chl-a ini dilakukan dengan melakukan validasi terhadap algoritma estimasi Chl-a yang diteliti Jaelani (2015) yang selanjutnya akan di uji dengan beberapa metode koreksi atmosfer dan hasilnya akan dikaji melalui data satelit terhadap data in-situ dari beberapa titik sampel yang ditentukan [6].

Estimasi parameter kualitas perairan (seperti: konsentrasi Chl-a) dari data satelit penginderaan jauh sangat bergantung, tidak hanya pada keakuratan koreksi atmosfer, tetapi juga pada keakuratan model yang menghubungkan antara data reflektan penginderaan jauh dengan parameter kualitas air yang akan diekstrak [7]. Dalam penelitian ini akan dilakukan suatu pemodelan ulang pada algoritma estimasi Chl-a untuk perairan selatan Pulau Lombok, NTB. 


\section{METODOLOGI PENELITIAN}

\section{A. Lokasi Penelitian}

Lokasi penelitian ini berada di perairan laut selatan Pulau Lombok, NTB yang terletak pada koordinat $8^{\circ} 54^{\prime} 28,83^{\prime \prime} \mathrm{LS}-8^{\circ}$ $55^{\prime} 3,18^{\prime \prime} \mathrm{LS}$ dan $116^{\circ} 19^{\prime} 18,74^{\prime \prime B T ~-~} 116^{\circ} 19^{\prime}$ 51,38“BT dengan garis pantai sepanjang $52,6 \mathrm{~km}$.

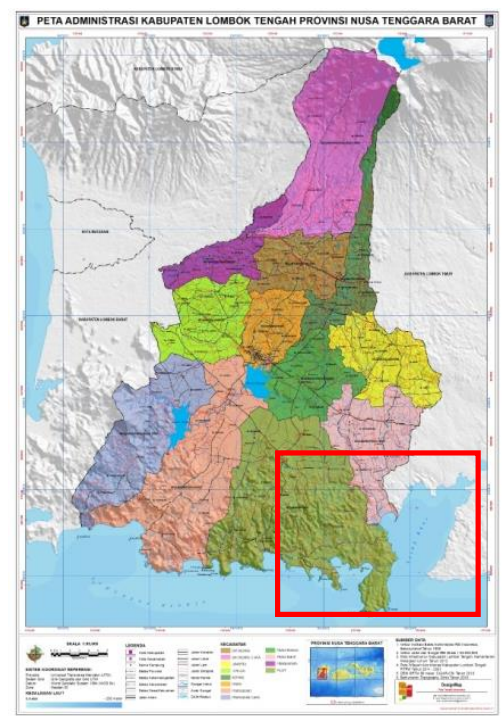

Gambar 1. Lokasi Penelitian

\section{B. Data dan Peralatan}

Data yang digunakan dalam penelitian tugas akhir ini adalah data citra satelit Landsat 8 Level 1T (L1T) dengan waktu akuisisi 19 September 2014 pada path/row 116/66, data Reflektan Permukaan (Surface Reflectance) citra satelit Landsat 8 produk USGS dengan waktu akuisisi 19 September 2014 pada path/row 116/66, data spektral perairan dan data sampel perairan selatan Pulau Lombok, NTB (data in-situ) dari Lembaga Penerbangan dan Antariksa Nasional (LAPAN) dengan waktu pengambilan data tanggal 18-22 September 2014.

Adapun peralatan yang digunakan dalam penelitian tugas akhir ini berupa perangkat keras (Hardware) yaitu Spectroradiometer dan perangkat lunak (Software) antara lain Beam VISAT 5.0, Second Simulation of a Satellite Signal in the Solar Spectrum-Vector (6SV), ArcGIS 10.3, dan ESA SNAP 3.0

\section{Tahap Pengolahan Data}

Data in-situ yang digunakan dalam penelitian ini didapatkan dari Lembaga Penerbangan Antariksa Nasional (LAPAN) pada perairan selatan Pulau Lombok, NTB yang diambil pada tanggal 18-22 September 2014 yang meliputi data kualitas perairan yang berupa konsentrasi Chl-a dan data reflektan. Pengukuran dilakukan dengan mengambil data sample Chl-a pada 29 titik dan pengambilan data reflektan pada 8 titik. Data reflektan yang direkam adalah reflektan kanal 1 hingga kanal 5.

Sesuai dengan ketersediaan data konsentrasi Chl-a dan data reflektan in-situ, data citra yang digunakan dalam penelitian ini adalah data citra Landsat 8 . Ada 2 produk Landsat yang digunakan, antara lain : 1) data Landsat 8 Level 1T (L1T) dan
2) data reflektan-permukaan (surface reflectance). Kedua data tersebut didapatkan atau dipesan secara gratis pada http://earthexplorer.usgs.gov/.

Data Landsat 8 Level 1T merupakan data citra mentah dan berformat Digital Number (DN). Langkah awal adalah melakukan kalibrasi radiometrik dengan menggunakan parameter Gain dan Offset yang tersedia dalam metadata citra dengan hasil data dalam format radian (L).

$$
\mathrm{L}_{\lambda}=\mathrm{M}_{\mathrm{L}} \mathrm{Q}_{\mathrm{cal}}+\mathrm{A}_{\mathrm{L}}
$$

dimana,

$$
\begin{aligned}
& \mathrm{L}_{\lambda}=\text { TOA spectral radiance } \\
& \mathrm{M}_{\mathrm{L}}=\text { Radiance Mult Band } \\
& \mathrm{A}_{\mathrm{L}}=\text { Radiance Add Band } \\
& \mathrm{Q}_{\text {cal }}=\text { Nilai Digital }(\mathrm{DN}) \text { Band }
\end{aligned}
$$

Selanjutnya dilakukan koreksi atmosfer dari data dalam format radian tersebut. Dalam penelitian ini akan dilakukan 2 metode koreksi atmosfer: 1) koreksi atmosfer 6SV dan 2) koreksi atmosfer Flaash.

Koreksi atmosfer metode 6SV menggunakan parameter koreksi dari hasil simulasi menggunakan Second Simulation of a Satellite Signal in the Solar Spectrum-Vector (6SV) yang di run atau di akses pada http://6s.ltdri.org/. Parameter koreksinya adalah sebagai berikut :

$$
\begin{aligned}
& \mathrm{y}_{\lambda}=\mathrm{x}_{\mathrm{a} \lambda}\left(\mathrm{L}_{\lambda}\right)-\mathrm{x}_{\mathrm{b} \lambda} \\
& \operatorname{arc}_{\lambda}=\mathrm{y} /\left(1+\mathrm{x}_{\mathrm{c} \lambda} \mathrm{y}_{\lambda}\right)
\end{aligned}
$$

dimana, $\operatorname{arc}_{\lambda}$ adalah reflektan yang sudah terkoreksi dari efek atmosfer dan $\mathrm{L}_{\lambda}$ adalah nilai radian TOA.

Tabel 1 .

Parameter Koreksi Atmosfer 6SV

\begin{tabular}{cccc}
\hline \hline Kanal & $\mathrm{Xa}_{\mathrm{a}}$ & $\mathrm{Xb}$ & $\mathrm{Xc}_{\mathrm{c}}$ \\
\hline Kanal 1 & 0,00278 & 0,19026 & 0,24680 \\
Kanal 2 & 0,00248 & 0,14204 & 0,21420 \\
Kanal 3 & 0,00255 & 0,09113 & 0,17026 \\
Kanal 4 & 0,00283 & 0,06534 & 0,14291 \\
Kanal 5 & 0,00417 & 0,04408 & 0,11508
\end{tabular}

Dalam koreksi atmosfer 6SV ini, dalam mendefinisikan konsentrasi aerosol digunakan parameter meteorologi berupa horizontal visibility (pada penelitian ini, digunakan visibility sebesar 7,91 km). Adapun erosol optical thickness pada 550nm dihitung berdasarkan profil aerosol daerah penelitian yaitu maritime model. Hasil dari koreksi atmosfer dengan metode 6SV selanjutnya disebut SR-6SV.

Koreksi atmosfer metode Flaash dilakukan dengan algoritma internal yang terdapat dalam software pengolahan citra penginderaan jauh. Dimana informasi dari parameter tersebut bisa dilihat melalui metadata citra. Prinsip utama dari koreksi atmosfer metode Flaash ini tidak jauh berbeda dengan metode $6 \mathrm{SV}$, yaitu dengan memasukkan beberapa parameter mengenai tanggal akuisisi citra, model atmosfer, model aerosol, dan visibility pada daerah penelitian. Selanjutnya hasil dari koreksi atmosfer dengan metode Flaash ini disebut SR-Flaash. 
Data reflektan-permukaan (surface reflectance) merupakan data citra yang sudah terkoreksi efek atmosfer yang diproses oleh USGS dengan menggunakan algoritma internal yang berbasis algoritma 6SV [7], [8]. Data reflektan-permukaan Landsat 8 ini selanjutnya disebut SR-L. Data SR-L selanjutnya dikalibrasi dengan membagi 10000 nilai Digital Number (DN) nya.

Untuk mendapatkan nilai reflektan yang sama dengan reflektan in-situ, maka reflektan yang telah terkoresi dari efek atmosfer, baik SR-6SV, SR-Flaash, dan SR-L akan dibagi dengan $\pi$ untuk mendapatkan $\operatorname{Rrs}(\lambda)$ (satuan $\mathrm{sr}^{-1}$ ). Langkah berikutnya digunakan algoritma Chl-a Jaelani untuk mengetahui nilai konsentrasi Chl-a estimasi pada masingmasing data $\operatorname{Rrs}(\lambda)$ baik dari $\operatorname{Rrs}(\lambda)-6 \mathrm{SV}, \operatorname{Rrs}(\lambda)$-Flaash, dan $\operatorname{Rrs}(\lambda)$-L. Algoritma Chl-a Jaelani adalah sebagai berikut.

$$
\log (\mathrm{Chl}-\mathrm{a})=-0,9889 \times\left(\operatorname{Rrs}_{4} / \operatorname{Rrs}_{5}\right)+0,3619
$$

Dalam menguji akurasi akurasi dari reflektan-permukan Landsat 8 digunakan indeks Normalized Mean Absolute Error (NMAE).

$$
\operatorname{NMAE}(\%)=\frac{1}{N} \sum_{i=1}^{N}\left|\frac{x \text { esti, } i-x \text { meas }, i}{x \text { meas }}\right| \times 100
$$

$\mathrm{X}_{\text {esti }}$ merupakan nilai dari estimasi konsentrasi Chl-a dengan menggunakan algoritma. $\mathrm{X}_{\text {meas }}$ adalah nilai konsentrasi Chl-a hasil pengukuran in-situ, sedangkan $\mathrm{N}$ adalah jumlah titik sampel. Koefisien determinasi $\left(R^{2}\right)$ juga tetap dihitung untuk mengetahui hubungan antara konsentrasi estimasi dan konsentrasi dari hasil pengukuran in-situ.

\section{HASIL DAN PEMBAHASAN}

\section{A. Validasi Remote Sensing Reflectance (Rrs) Landsat 8}

Untuk memvalidasi nilai $\operatorname{Rrs}(\lambda)$ yang sudah terkoreksi dari efek atmosfer baik dengan metode 6SV $(\operatorname{Rrs}(\lambda)-6 \mathrm{SV})$, Flaash $(\operatorname{Rrs}(\lambda)$-Flaash), dan produk reflektan-permukaan dari USGS $(\operatorname{Rrs}(\lambda)-\mathrm{L})$, dilakukan dengan mencari rata-rata nilai pixel dengan ukuran $3 \times 3$ berdasarkan pada 8 titik stasiun pengamatan yang nantinya dibandingkan dengan nilai $\operatorname{Rrs}(\lambda)$ in-situ. Hal ini dilakukan untuk menghindari kemungkinan adanya kesalahan dalam koreksi geometrik dan dinamika badan air, serta kesalahan akibat variabilitas spasial [9].

Data reflektan in-situ terdiri dari panjang gelombang mulai dari $319 \mathrm{~nm}$ hingga $953 \mathrm{~nm}$ yang artinya data $\operatorname{Rrs}(\lambda)$ in-situ hanya dapat digunakan untuk kanal 1 hingga kanal 5. Ketiga produk $\operatorname{Rrs}(\lambda)$ estimasi $(\operatorname{Rrs}(\lambda)$-6SV, $\operatorname{Rrs}(\lambda)$-Flaash, $\operatorname{Rrs}(\lambda)-\mathrm{L})$ menghasilkan data diatas data $\operatorname{Rrs}(\lambda)$ in-situ kecuali pada titik St. 6A dan St. 9A dimana $\operatorname{Rrs}(\lambda)$ estimasi menghasilkan data dibawah $\operatorname{Rrs}(\lambda)$ in-situ. Selain itu, bentuk spektral antara $\operatorname{Rrs}(\lambda)$ estimasi dan $\operatorname{Rrs}(\lambda)$ in-situ memiliki perbedaan.

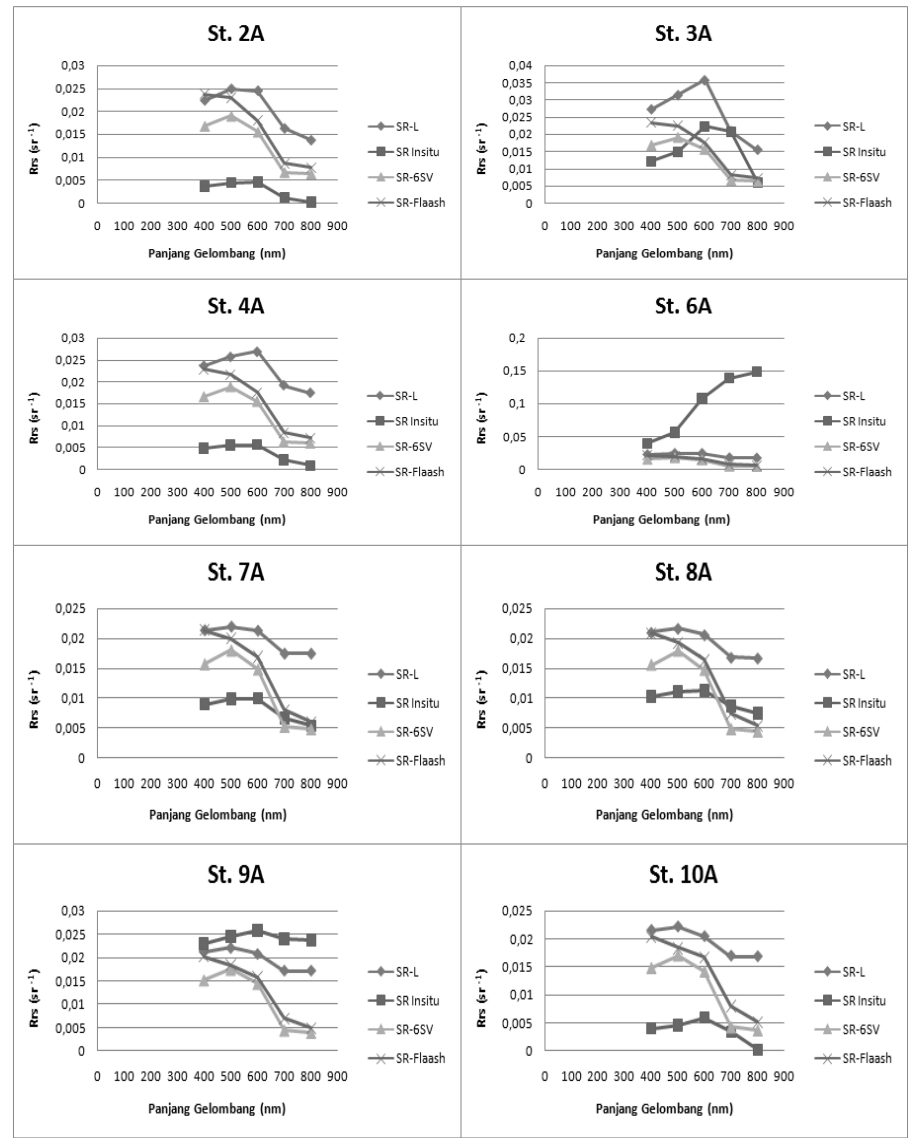

Gambar 2. Perbandingan $\operatorname{Rrs}(\lambda)$ In-situ dengan $\operatorname{Rrs}(\lambda)$ Estimasi baik $\operatorname{Rrs}(\lambda)-6 \mathrm{~V}$, $\operatorname{Rrs}(\lambda)$-Flaash, dan $\operatorname{Rrs}(\lambda)$-L

Hal tersebut dapat ditinjau karena adanya perbedaan algoritma internal saat pemrosesan metode koreksi atmosfer yang dilakukan. Selain itu, faktor algoritma koreksi atmosfer yang tidak sensitif terhadap aerosol.

Hasil koefisien determinasi $\left(R^{2}\right)$ antara $\operatorname{Rrs}(\lambda)$ in-situ dan $\operatorname{Rrs}(\lambda)$ estimasi dari 8 titik pada kanal 1 hingga kanal 5, menunjukkan hasil korelasi yang sangat besar $(0,495-0,997)$ untuk kesemua stasiun kecuali pada stasiun St. 3A dan St. 9A. Pada stasiun St. 3A menunjukkan korelasi terendah antara data $\operatorname{Rrs}(\lambda)$ In-situ dengan $\operatorname{Rrs}(\lambda)$-Flaash yang hanya sebesar 0,012 . Begitu juga pada stasiun St. 9A, nilai korelasi terendah ditunjukkan oleh data antara Rrs In-situ dengan $\operatorname{Rrs}(\lambda)$-Flaash yang hanya sebesar 0,003 . Korelasi antara $\operatorname{Rrs}(\lambda)$ in-situ dengan $\operatorname{Rrs}(\lambda)$ estimasi terbaik ditunjukkan oleh $\operatorname{Rrs}(\lambda)$-6SV dengan nilai $R^{2}$ sebesar 0,657 .

Tabel 2.

Koefisien Determinasi $\left(R^{2}\right)$ antara $\operatorname{Rrs}(\lambda)$ in-situ dengan $\operatorname{Rrs}(\lambda)$ estimasi

\begin{tabular}{cccc}
\hline \hline & \multicolumn{3}{c}{$\mathrm{R}^{2}$} \\
\cline { 2 - 4 } Stasiun & $\begin{array}{c}\text { Rrs }(\lambda) \text {-Insitu } \\
\text { dengan } \operatorname{Rrs}(\lambda) \text { - } \\
\text { 6SV }\end{array}$ & $\begin{array}{c}\operatorname{Rrs}(\lambda) \text {-Insitu } \\
\text { dengan } \\
\operatorname{Rrs}(\lambda) \text {-L }\end{array}$ & $\begin{array}{c}\operatorname{Rrs}(\lambda) \text {-Insitu } \\
\text { dengan } \operatorname{Rrs}(\lambda)- \\
\text { Flaash }\end{array}$ \\
\hline St. 2A & 0,997 & 0,899 & 0,8 \\
St. 3A & 0,372 & 0,037 & 0,012 \\
St. 4A & 0,972 & 0,914 & 0,836 \\
St. 6A & 0,607 & 0,798 & 0,926 \\
St. 7A & 0,921 & 0,908 & 0,839 \\
St. 8A & 0,85 & 0,855 & 0,779 \\
St. 9A & 0,042 & 0,054 & 0,003 \\
St. 10A & 0,495 & 0,584 & 0,605 \\
$\boldsymbol{R}^{2}$ rata-rata & $\mathbf{0 , 6 5 7}$ & $\mathbf{0 , 6 3 1 1 2 5}$ & $\mathbf{0 , 6}$ \\
\hline \hline
\end{tabular}




\section{B. Validasi Estimasi Konsentrasi Chl-a}

Dari masing-masing $\operatorname{Rrs}(\lambda)$ estimasi yaitu $\operatorname{Rrs}(\lambda)-6 \mathrm{SV}, \operatorname{Rrs}(\lambda)$ Flaash, dan $\operatorname{Rrs}(\lambda)$-L akan dihitung estimasi konsentrasi Chl-a dengan menggunakan algoritma Chl-a Jaelani yang kemudian akan di validasi dengan konsentrasi Chl-a in-situ pada 21 titik sampel lapangan.

Tabel 3.

Perbandingan Konsentrasi Chl-a In-situ dengan konsentrasi Chl-a Estimasi

\begin{tabular}{ccccc}
\hline \multirow{3}{*}{ Stasiun } & \multicolumn{4}{c}{ Konsentrasi Chl-a $(\mu \mathrm{g} / \mathrm{L})$} \\
\cline { 2 - 5 } & In-situ & SR & 6 SV & Flaash \\
\hline 1 & 1,207 & 0,187 & 0,111 & 0,162 \\
2 & 0,868 & 0,187 & 0,111 & 0,162 \\
3 & 0,645 & 0,085 & 0,012 & 0,055 \\
4 & 0,543 & 0,126 & 0,132 & 0,108 \\
5 & 0,662 & 0,196 & 0,217 & 0,264 \\
6 & 0,969 & 0,205 & 0,228 & 0,229 \\
7 & 0,986 & 0,210 & 0,306 & 0,262 \\
8 & 0,662 & 0,236 & 0,320 & 0,286 \\
9 & 0,543 & 0,236 & 0,320 & 0,287 \\
10 & 0,544 & 0,236 & 0,322 & 0,287 \\
11 & 0,662 & 0,237 & 0,333 & 0,296 \\
12 & 0,646 & 0,234 & 0,302 & 0,277 \\
13 & 0,646 & 0,230 & 0,308 & 0,262 \\
14 & 0,544 & 0,226 & 0,204 & 0,253 \\
15 & 0,662 & 0,240 & 0,299 & 0,251 \\
16 & 0,646 & 0,240 & 0,335 & 0,286 \\
17 & 1,071 & 0,223 & 0,269 & 0,279 \\
18 & 1,173 & 0,062 & 0,012 & 0,022 \\
19 & 0,986 & 0,225 & 0,2413 & 0,226 \\
20 & 0,969 & 0,231 & 0,251 & 0,214 \\
21 & 2,445 & 0,033 & 0,048 & 0,009 \\
\hline \hline
\end{tabular}

Tabel 4.

Perhitungan NMAE dari Konsentrasi Chl-a

\begin{tabular}{cccc}
\hline \hline & & NMAE $(\%)$ \\
\cline { 2 - 4 } Stasiun & SR & 6 SV & Flaash \\
\hline 1 & 41,731 & 44,845 & 42,731 \\
2 & 27,866 & 30,980 & 28,865 \\
3 & 22,895 & 25,900 & 24,131 \\
4 & 17,066 & 16,790 & 17,774 \\
5 & 19,058 & 18,212 & 16,273 \\
6 & 31,239 & 30,305 & 30,247 \\
7 & 31,738 & 27,793 & 29,608 \\
8 & 17,407 & 13,970 & 15,371 \\
9 & 12,573 & 9,117 & 10,453 \\
10 & 12,600 & 9,089 & 10,523 \\
11 & 17,402 & 13,452 & 14,961 \\
12 & 16,827 & 14,069 & 15,090 \\
13 & 17,029 & 13,844 & 15,697 \\
14 & 13,021 & 13,921 & 11,908 \\
15 & 17,246 & 14,853 & 16,830 \\
16 & 16,604 & 12,706 & 14,710 \\
17 & 34,698 & 32,786 & 32,371 \\
18 & 45,459 & 47,497 & 47,061 \\
19 & 31,116 & 30,459 & 31,069 \\
20 & 30,200 & 29,370 & 30,884 \\
21 & 98,657 & 98,034 & 99,632 \\
Rata-rata & $\mathbf{2 7 , 2 5 9}$ & $\mathbf{2 6 , 0 9 5}$ & $\mathbf{2 6 , 4 8 5}$ \\
\hline \hline
\end{tabular}

Sebagian besar stasiun mempunyai NMAE yang memenuhi syarat yakni kurang dari $30 \%$. Hasil NMAE terbaik adalah dari citra Landsat 8 dengan koreksi atmosfer metode 6SV yaitu sebesar 26,095\%. Dari ketiga macam produk tersebut dengan menggunakan algoritma Chl-a Jaelani dapat digunakan untuk mengestrak atau mewakili data kualitas air dari penginderaan jauh karena memenuhi syarat NMAE yang kurang dari $30 \%$.
Akan tetapi pada penelitian ini tetap akan dibuat algoritma model untuk estimasi konsentrasi Chl-a di wilayah perairan laut selatan Pulau Lombok, NTB.

\section{Pemodelan Algoritma Estimasi Konsentrasi Chl-a}

Algoritma model konsentrasi Chl-a dibuat berdasarkan pada regresi algoritma yang dibentuk dari perbandingan kanal-kanal pada Landsat 8, seperti yang ditunjukkan pada Tabel 5 dan 6.

Tabel 5.

$R^{2}$ untuk Rasio-Kanal Landsat 8

\begin{tabular}{lccc}
\hline \multirow{2}{*}{ Model Regresi } & Kanal 2 & Kanal 2 & Kanal 2 \\
\cline { 2 - 4 } & Kanal 3 & Kanal 4 & Kanal 5 \\
\hline Chl-a = y0 + a*(bj/bk) & 0,07 & 0,013 & 0,18 \\
$\log (\mathrm{Chl}-\mathrm{a})=\mathrm{y} 0+\mathrm{a}^{*}(\mathrm{bj} / \mathrm{bk})$ & 0,041 & 0,005 & 0,347 \\
Chl-a = y0 + a* $\log (\mathrm{bj} / \mathrm{bk})$ & 0,087 & 0,007 & 0,187 \\
$\log (\mathrm{Chl}-\mathrm{a})=\mathrm{y0}+\mathrm{a}^{*} \log (\mathrm{bj} / \mathrm{bk})$ & 0,048 & 0,019 & 0,26 \\
Chl-a = y0 + a*(log $(\mathrm{bj}) /$ & 0,159 & 0,092 & 0,28 \\
$(\log (\mathrm{bk}))$ & 0,077 & 0,066 & 0,218 \\
$\log (\mathrm{Chl}-\mathrm{a})=\mathrm{y0}+\mathrm{a}^{*}(\log (\mathrm{bj}) /$ & & & \\
$(\log (\mathrm{bk}))$ &
\end{tabular}

Tabel 6.

$R^{2}$ untuk Rasio-Kanal Landsat 8

\begin{tabular}{|c|c|c|c|}
\hline \multirow{2}{*}{ Model Regresi } & Kanal 3 & Kanal 3 & Kanal 4 \\
\hline & Kanal 4 & Kanal 5 & Kanal 5 \\
\hline Chl-a $=y 0+a^{*}(b j / b k)$ & 0,02 & 0,137 & 0,537 \\
\hline $\log (\mathrm{Chl}-\mathrm{a})=\mathrm{y} 0+\mathrm{a}^{*}(\mathrm{bj} / \mathrm{bk})$ & 0,011 & 0,268 & 0,511 \\
\hline Chl-a $=$ y0 $+a^{*} \log (b j / b k)$ & 0 & 0,165 & 0,458 \\
\hline $\log ($ Chl-a $)=y 0+a^{*} \log (b j / b k)$ & 0,009 & 0,252 & 0,47 \\
\hline $\begin{array}{l}\text { Chl-a }=y 0+a *(\log (b j) / \\
(\log (b k))\end{array}$ & 0,029 & 0,259 & 0,551 \\
\hline $\begin{array}{l}\log (\text { Chl-a })=y 0+a *(\log (b j) / \\
(\log (b k))\end{array}$ & 0,039 & 0,255 & 0,529 \\
\hline
\end{tabular}

Dari beberapa kombinasi, didapatkan koefisien determinasi $R^{2}=0.551$ dengan perbandingan rasio $\operatorname{Rrs}\left(\lambda_{4}\right) / \operatorname{Rrs}\left(\lambda_{5}\right)$ dengan algoritma model estimasi konsentrasi Chl-a sebagai berikut:

$$
\text { Chl-a }=2,223\left(\frac{\log \operatorname{Rrs}\left(\lambda_{4}\right)}{\log \operatorname{Rrs}\left(\lambda_{5}\right)}\right)-1,439
$$

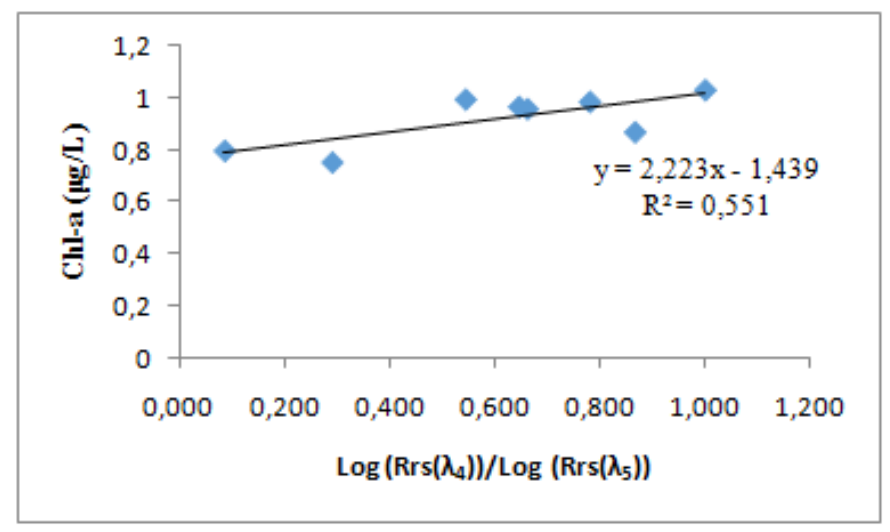

Gambar 3. Model Regresi dengan menggunakan rasio $\operatorname{Rrs}(\lambda)$ pada kanal 4 dan kanal 5

Dari masing-masing $\operatorname{Rrs}(\lambda)$ estimasi yaitu $\operatorname{Rrs}(\lambda)-6 \mathrm{SV}$, $\operatorname{Rrs}(\lambda)$-Flaash, dan $\operatorname{Rrs}(\lambda)$ - $\mathrm{L}$ akan dihitung estimasi konsentrasi Chl-a dengan menggunakan algoritma model Chl-a sesuai dengan Pers.6 yang kemudian akan di validasi dengan konsentrasi Chl-a in-situ pada 21 titik sampel lapangan. 
Tabel 7.

Perbandingan Konsentrasi Chl-a In-situ dengan konsentrasi Chl-a Estimasi

\begin{tabular}{ccccc}
\hline \multirow{2}{*}{ Stasiun } & \multicolumn{4}{c}{ Konsentrasi Chl-a $(\boldsymbol{\mu g} / \mathbf{L})$} \\
\cline { 2 - 5 } & $\mathbf{I n}$-situ & $\mathbf{S R}$ & $\mathbf{6 S V}$ & Flaash \\
\hline 1 & 1,207 & 0,730 & 0,638 & 0,700 \\
2 & 0,868 & 0,730 & 0,638 & 0,700 \\
3 & 0,645 & 0,581 & 0,397 & 0,527 \\
4 & 0,543 & 0,643 & 0,657 & 0,611 \\
5 & 0,662 & 0,737 & 0,763 & 0,808 \\
6 & 0,969 & 0,751 & 0,777 & 0,777 \\
7 & 0,986 & 0,755 & 0,840 & 0,805 \\
8 & 0,662 & 0,784 & 0,850 & 0,830 \\
9 & 0,543 & 0,784 & 0,849 & 0,831 \\
10 & 0,544 & 0,784 & 0,850 & 0,830 \\
11 & 0,662 & 0,784 & 0,857 & 0,838 \\
12 & 0,646 & 0,782 & 0,837 & 0,823 \\
13 & 0,646 & 0,777 & 0,840 & 0,808 \\
14 & 0,544 & 0,773 & 0,754 & 0,799 \\
15 & 0,662 & 0,788 & 0,765 & 0,734 \\
16 & 0,646 & 0,788 & 0,860 & 0,822 \\
17 & 1,071 & 0,770 & 0,808 & 0,830 \\
18 & 1,173 & 0.528 & 0,395 & 0,428 \\
19 & 0,986 & 0,773 & 0,789 & 0,775 \\
20 & 0,969 & 0,778 & 0,802 & 0,762 \\
21 & 2,445 & 0,398 & 0,435 & 0,212 \\
\hline \hline
\end{tabular}

Tabel 8.

Perhitungan NMAE dari Konsentrasi Chl-a

\begin{tabular}{cccc}
\hline \hline & & \multicolumn{3}{c}{$\boldsymbol{N M A E}(\boldsymbol{\%})$} \\
\cline { 2 - 4 } Stasiun & $\mathbf{S R}$ & $\mathbf{6 S V}$ & Flaash \\
\hline 1 & 21,195 & 23,264 & 20,741 \\
2 & 9,330 & 9,399 & 6,876 \\
3 & 7,273 & 10,134 & 4,830 \\
4 & 5,461 & 4,654 & 4,770 \\
5 & 4,783 & 4,134 & 5,974 \\
6 & 9,910 & 7,867 & 7,853 \\
7 & 10,178 & 5,972 & 7,386 \\
8 & 8,373 & 7,707 & 6,878 \\
9 & 12,166 & 12,535 & 11,784 \\
10 & 10,154 & 12,527 & 11,700 \\
11 & 7,377 & 7,984 & 7,190 \\
12 & 5,864 & 7,817 & 7,223 \\
13 & 5,437 & 7,939 & 7,645 \\
14 & 10,267 & 8,570 & 10,420 \\
15 & 5,712 & 4,222 & 4,953 \\
16 & 6,340 & 8,772 & 7,202 \\
17 & 12,547 & 10,737 & 11,859 \\
18 & 31,452 & 31,838 & 30,480 \\
19 & 8,754 & 8,045 & 8,642 \\
20 & 7,663 & 6,819 & 8,471 \\
21 & 88,064 & 82,217 & 91,340 \\
Rata-rata & $\mathbf{1 3 , 7 2 8}$ & $\mathbf{1 3 , 4 8 4}$ & $\mathbf{1 3 , 5 3 4}$ \\
\hline \hline
\end{tabular}

Sebagian besar stasiun mempunyai $N M A E$ yang memenuhi syarat yakni kurang dari $30 \%$. Hasil NMAE terbaik adalah dari citra Landsat 8 dengan koreksi atmosfer metode 6SV yaitu sebesar $13,484 \%$. Dari ketiga macam produk tersebut dengan menggunakan algoritma model Chl-a baru dapat digunakan untuk mengestrak atau mewakili data kualitas air dari penginderaan jauh karena memenuhi syarat $N M A E$ yang kurang dari $30 \%$. Hasil NMAE dengan algoritma model baru memiliki nilai yang lebih baik dibandingkan dengan algoritma Chl-a Jaelani.

\section{Estimasi Distribusi Konsentrasi Chl-a}

Berikut ini estimasi konsentrasi Chl-a dengan model algoritma Chl-a baru.
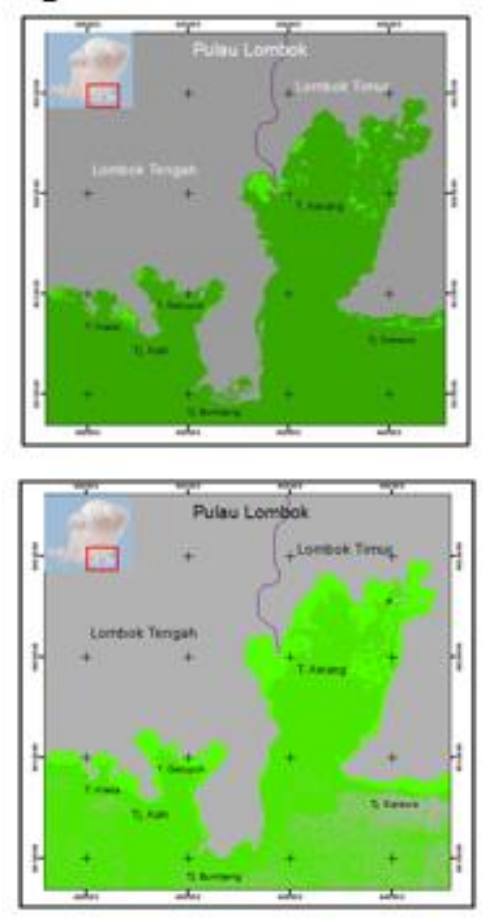

Legenda

Gambar 4. Distribusi Estimasi Konsentrasi Chl-a : a) SR-L, b) SR-6SV, c) SRFlaash

\section{KESIMPULAN}

Hasil validasi konsentrasi Chl-a pada algoritma Chl-a Jaelani dengan menggunakan metode koreksi atmosfer 6SV menunjukkan nilai $N M A E$ yang lebih baik dibandingkan dengan menggunakan metode koreksi atmosfer Flaash yaitu sebesar 26,095\%. Sedangkan dengan menggunakan metode koreksi atmosfer Flaash didapatkan nilai NMAE sebesar 26,485\% dan dari data reflektan-permukaan Landsat 8 sebesar $27,259 \%$. Dari ketiga macam produk tersebut dengan menggunakan algoritma Chl-a Jaelani dapat digunakan untuk mengestrak atau mewakili data kualitas air dari penginderaan jauh karena memenuhi syarat NMAE yang kurang dari $30 \%$. Berdasarkan nilai NMAE tersebut menunjukkan bahwa algoritma Chl-a Jaelani dapat digunakan untuk menghitung nilai estimasi konsentrasi Chl-a di perairan laut selatan Pulau Lombok, Nusa Tenggara Barat.

Pemodelan algoritma yang dibuat berdasarkan pada regresi algoritma yang dibentuk dari perbandingan kanal-kanal pada Landsat 8. Dari hasil pemodelan algoritma Chl-a didapatkan regresi $\left(R^{2}\right)$ sebesar 0,551 dengan perbandingan rasio $\operatorname{Rrs}\left(\lambda_{4}\right) /$ $\operatorname{Rrs}\left(\lambda_{5}\right)$ dengan algoritma model estimasi konsentrasi Chl-a sebagai berikut:

$$
\text { Chl-a }=2,223\left(\frac{\log \operatorname{Rrs}\left(\lambda_{4}\right)}{\log \operatorname{Rrs}\left(\lambda_{5}\right)}\right)-1,439
$$

Hasil validasi konsentrasi Chl-a dengan algoritma model Chl-a baru memiliki $N M A E$ terbaik dari citra Landsat 8 dengan koreksi atmosfer metode $6 \mathrm{SV}$ yaitu sebesar $13,484 \%$. Hal ini 
menunjukkan bahwa algoritma model Chl-a baru untuk perairan laut selatan Pulau Lombok lebih baik dalam mengekstrak data kualitas air dari data penginderaan jauh pada lokasi penelitian dibandingkan dengan algoritma Chl-a Jaelani.

\section{UCAPAN TERIMA KASIH}

Penelitian ini didukung oleh Lembaga Penerbangan dan Antariksa Nasional (LAPAN) Jakarta Timur.

\section{DAFTAR PUSTAKA}

[1] B. P. S. P. NTB, "Nusa Tenggara Barat dalam Angka 2012," Lombok, 2014.

[2] Musbir, A. I. Burhanuddin, N. N. and N. A., "Perairan Oseanografi dalam Pemanfaatan Sumber Daya Perikanan Berkelanjutan dalam Membangun Sumber Daya Kelautan Indonesia," IPB Press, Bogor, 2013.

[3] Adnan, "Analisis Suhu Permukaan Laut dan Klorofil-a Data Inderaja Hubungannya dengan Hasil Tangkapan Ikan Tongkol (Euthynnus Affinis) di Perairan Kalimantan Timur," Jurnal FPIK Unpatti, Ambon, vol. I, no. 1, pp. 1-12, 2010.

[4] M. S. Pangihutan, "Analisis Hasil Tangkapan Pukat Ikan Kaitannya dengan Kandungan Klorofil-a dan Suhu Permukaan Laut di Perairan Tapanuli Tengah," Thesis Program Pascasarjana: Institut Pertanian Bogor, Bogor, 2009.

[5] J. D. H. Srrickland and T. R. Parsons, Apreactical Handbook of Sea Water Analysis, Canada: Fis. Res. Board, 1960.

[6] K. G. Ruddick, F. Ovidio and M. Rijkeboer, "Atmospheric Correction of SeaWiFS Imagery for Turbid Coastal and Inland Waters," Applied Optics, vol. 39, no. 6, pp. 897-912, 2000.

[7] L. M. Jaelani, "Pemetaan Distribusi Spasial Konsentrasi Klorofil-a dengan Landsat 8 di Danau Matano dan Danau Towuti Sulawesi Selatan," in Prosiding Pertemuan Ilmiah Tahunan Masyarakat Ahli Penginderaan Jauh Indonesia XX, Bogor, 2015.

[8] L. M. Jaelani, "Uji Akurasi Produk Reflektan Permukaan Landsat menggunakan Data In Situ di Danau Kasumigaura Jepang," in Prosiding Pertemuan Ilmiah Tahunan Masyarakat Ahli Oenginderaan Jauh Indonesia XX, Bogor, 2015.

[9] L. Han and J. J. Karen, "Estimating and Mapping Chlorophyll-a Concentration in Pensacola Bay, Florida using Landsat ETM+ Data," International Journal of Remote Sensing, vol. 26, no. 33, pp. 5245-5254, 2005. 